\title{
Laser Metal Deposition of an AlCoCrFeNiTi 0.5 High-Entropy Alloy Coating on a Ti6A14V Substrate: Microstructure and Oxidation Behavior
}

\author{
Wenyuan Cui ${ }^{1, *}$, Wei $\mathrm{Li}^{2}$, Wei-Ting Chen ${ }^{3}$ and Frank Liou ${ }^{1}$ \\ 1 Department of Mechanical and Aerospace Engineering, Missouri University of Science and Technology, \\ Rolla, MO 65409, USA; liou@mst.edu \\ 2 Department of Mechanical Engineering, University of Texas at Dallas, Richardson, TX 75080, USA; \\ wei.li@utdallas.edu \\ 3 Materials Research Center, Missouri University of Science and Technology, Rolla, MO 65409, USA; \\ chenweit@mst.edu \\ * Correspondence: wcz68@umsystem.edu; Tel.: +1-573-341-4661
}

Received: 15 June 2020; Accepted: 21 July 2020; Published: 23 July 2020

\begin{abstract}
Ti6Al4V has been recognized as an attractive material, due to its combination of low density and favorable mechanical properties. However, its insufficient oxidation resistance has limited the high-temperature application. In this work, an $\mathrm{AlCoCrFeNiTi}_{0.5}$ high-entropy alloy (HEA) coating was fabricated on a Ti6Al4V substrate using laser metal deposition (LMD). The microstructure and isothermal oxidation behaviors were investigated. The microstructure of as-deposited HEA exhibited a Fe, Cr-rich $\mathrm{A} 2$ phase and an $\mathrm{Al}, \mathrm{Ni}$, Ti-enriched B2 phase. Its hardness was approximately 2.1 times higher than that of the substrate. The oxidation testing at $700{ }^{\circ} \mathrm{C}$ and $800{ }^{\circ} \mathrm{C}$ suggested that the HEA coating has better oxidation resistance than the Ti6Al4V substrate. The oxide scales of the Ti6Al4V substrate were mainly composed of $\mathrm{TiO}_{2}$, while continuous $\mathrm{Al}_{2} \mathrm{O}_{3}$ and $\mathrm{Cr}_{2} \mathrm{O}_{3}$ were formed in the HEA coatings and could be attributed to oxidation resistance improvement. This work provides an approach to mitigate the oxidation resistance of Ti6Al4V and explore the applicability of the HEA in a high-temperature environment.
\end{abstract}

Keywords: high-entropy alloy; oxidation behavior; additive manufacturing; laser metal deposition

\section{Introduction}

Ti6Al4V has been an important and versatile titanium alloy currently used in petrochemical, automotive, power generation, and biomedical industries. Indeed, this alloy possesses a desirable combination of properties, such as high melting point, superior corrosion resistance, good biocompatibility, and weldability [1-3]. However, Ti6Al4V alloy is very active at elevated temperature, which results in being easily oxidized, as well as its insufficient oxidation resistance $[4,5]$. At present, the permitted maximal service temperature of Ti6Al4V alloy still does not exceed $600{ }^{\circ} \mathrm{C}[1,4]$. The improvement of its high-temperature oxidation property can be solved by the surface modification process [3-6].

As a promising surface modification technology, laser metal deposition (LMD) has introduced a number of capabilities unparalleled by conventional process [3,6-11]. LMD achieves layer-by-layer fabrication of near net-shaped deposition onto the substrate by introducing a powder stream into a laser beam. In addition to the geometry freedom, precise tailoring of compositions and microstructure can be achieved to produce highly specialized coatings. On the basis of these advantages, many efforts have been made to improve the oxidation resistance of Ti6Al4V alloy. In particular, Liu et al. prepared a $\mathrm{TiN} / \mathrm{Ti}_{3} \mathrm{Al}$ composite coating on the Ti6Al4V substrate [12]. The isothermal oxidation results indicated 
that the relative oxidation resistance of the coating was approximately six times higher than that of the substrate at $600{ }^{\circ} \mathrm{C}$, due to the formation of $\mathrm{TiN}, \mathrm{Al}_{2} \mathrm{O}_{3}$, and $\mathrm{TiO}_{2}$. A titanium-aluminum alloy (Ti48Al2 $\mathrm{Cr} 2 \mathrm{Nb}$ ) was adopted as a coating material and demonstrated good anti-oxidation property in comparison with the Ti6Al4V at $800{ }^{\circ} \mathrm{C}$ [13]. Successive layers of oxides (up to $12 \mu \mathrm{m}$ thick) were formed on the Ti48Al2 $\mathrm{Cr} 2 \mathrm{Nb}$ after $150 \mathrm{~h}$ of oxidation, while the oxide layers detached from the Ti6Al4V after $5 \mathrm{~h}$. A gradient Ti-Ni alloy was fabricated by laser cladding, and a dense $\mathrm{Al}_{2} \mathrm{O}_{3}$ layer was formed, inhibiting the further diffusion of oxygen atoms under $800{ }^{\circ} \mathrm{C}$ [14]. Wang et al. manufactured a $\mathrm{Ti}_{5} \mathrm{Si}_{3} / \gamma / \mathrm{TiSi}$ composite coating, in which the presence of continuous $\mathrm{Al}_{2} \mathrm{O}_{3}$ and $\mathrm{SiO}_{2}$ scales contributed to the high-temperature oxidation resistance [15]. The authors also discovered that $\mathrm{Ti}_{5} \mathrm{Si}_{3}$ and $\mathrm{TiSi}$ possessed brittleness at room temperature, and the shedding was observed on the worn face of the coatings. Although the titanium silicide-based materials mentioned above can have an excellent high-temperature oxidation resistance, they also bring some issues, such as the brittleness at room temperature and high cracking susceptibility $[2,6,15]$.

An important concept of "High-entropy alloys (HEAs)" has broken the traditional idea of alloy design based on one or two principal components [16-18]. This new class of alloys typically contain 5 to 13 principal elements, and the concentration of each element is between 5 and 35 atomic percent. The high-entropy effect of HEAs is beneficial to the formation of the solid solution with crystal structures such as face-centered cubic (FCC), body-centered cubic (BCC), or hexagonal close-packed (HCP), instead of too many complex intermetallic compounds. Among a variety kind of HEAs, $\mathrm{Al}-\mathrm{Co}-\mathrm{Cr}-\mathrm{Fe}-\mathrm{Ni}$ has been one of the most developed and refined systems. The equimolar $\mathrm{AlCoCrFeNi}$ alloy exhibited dendritic and interdendritic microstructures, which were composed of CrFe-rich precipitates embedded in an AlNi-rich matrix $[19,20]$. After the ageing treatments at $800{ }^{\circ} \mathrm{C}, 1000{ }^{\circ} \mathrm{C}$, and $1200{ }^{\circ} \mathrm{C}$, the precipitation of an FCC phase resulted in reduced compressive yield strength accompanied by enhanced ductility [21]. Concerning the oxidation resistance, the sluggish diffusion kinetics has been found, and it can restrain the formation of non-protective transient oxides [22,23]. Mohanty et al. investigated two types of $\mathrm{HEAs}\left(\mathrm{Al}_{0.3} \mathrm{CoCrFeNi}\right.$ and $\left.\mathrm{Al}_{0.7} \mathrm{CoCrFeNi}\right)$ and reported that the thickness of the oxide layer increased with the content of $\mathrm{Al}$ [24]. The oxidation behaviors of a series of arc-melted $\mathrm{Al}_{\mathrm{x}}(\mathrm{NiCoCrFe})_{100-\mathrm{x}}(\mathrm{x}=8,10,12,15,20$ and 30 atomic\%) and $\mathrm{AlCoCrFeNi}(\mathrm{Fe}$ or Si) HEAs were studied by Butler et al. [25,26]. The oxide scales contained a combination of $\mathrm{Al}_{2} \mathrm{O}_{3}, \mathrm{AlN}$ beneath, and external $\mathrm{Cr}_{2} \mathrm{O}_{3}$ scale. Each HEA exhibited initial transient oxidation followed by parabolic oxide growth. The oxidation study of $\mathrm{AlCoCrCu}_{x} \mathrm{FeNi}(\mathrm{x}=0,0.5,1$ in molar ratio) revealed the parabolic constants were at the same level as those Al-Ni intermetallic alloys [27]. The oxide scales consisted of $\alpha-\mathrm{Al}_{2} \mathrm{O}_{3}$ and were visible on the oxidation surface of these HEAs. The addition of Ti could lead to solid solution strengthening and precipitation strengthening in $\mathrm{Al}_{1.5} \mathrm{CrFeMnTi}$ and $\mathrm{AlCoCrFeNiTi} \mathrm{i}_{\mathrm{x}}$ HEAs $[28,29]$. The study of $\mathrm{Al}_{x} \mathrm{CoCrFeNiTi}_{1-\mathrm{x}}(\mathrm{x}=1,0.8,0.5$ in molar ratio) indicated that Ti promoted the formation of FCC phase, and Al resulted in BCC phase [30]. Nevertheless, these HEAs have been mainly prepared by arc melting [25-27,29,30], thermal spray technique [31], and the electrospark process [32]. Therefore, it is desirable to laser fabricate an $\mathrm{AlCoCrFeNiTi}_{0.5}$ HEA coating and evaluate its oxidation performance.

This work aimed to investigate the microstructure and oxidation behavior of an $\mathrm{AlCoCrFeNiTi}_{0.5}$ HEA coating synthesized on the Ti6Al4V substrate by laser metal deposition. Microstructural characterization was performed on the as-deposited HEA coating. Then, the isothermal oxidation test was conducted to evaluate its oxidation behaviors at elevated temperatures. The weight change, phase constitutions, and cross-sectional morphology after oxidation were analyzed and discussed. 


\section{Materials and Methods}

\subsection{Sample Preparation}

$\mathrm{AlCoCrFeNiTi}_{0.5}$ HEA samples with the nominal composition (as shown in Table 1) were prepared by LMD. Spherical gas-atomized elemental powder blends were used. The powders of $\mathrm{Al}, \mathrm{Co}, \mathrm{Cr}, \mathrm{Fe}, \mathrm{Ni}$, and Ti were supplied by Micron Metals (Ramapo, NJ, USA) with 99.9\% purity and 44-145 $\mu$ m particle size distribution. The powder mixture (total: $276.5 \mathrm{~g}$ ) was prepared by carefully weighing the powders using a weighing balance with an accuracy of $\pm 0.1 \mathrm{mg}$. The mixed powders were homogenized in a Turbula mixer (Glen Mills Inc., Clifton, NJ, USA) for $1 \mathrm{~h}$. The experimental setup consisted of an IPG $1 \mathrm{~kW}$ continuous wave YAG fiber laser (IPG Photonics, Oxford, MA, USA), a numerical control working table, and a vibration powder feeder (Powder Motion Labs, Rolla, MO, USA), as shown in Figure 1. The Grade 5 Ti6Al4V bar stock was used as the substrates (dimensions $75 \mathrm{~mm} \times 12 \mathrm{~mm} \times 6 \mathrm{~mm}$ ) and cleaned with acetone to remove the dirt and oil before the experiment. The deposition process was performed in a sealed, controlled environment purged with a continuous flow of argon gas. A pre-heating was undertaken to minimize the thermal stress between the deposit and the Ti6 Al4V substrate. The powders were delivered to the laser beam by an argon jet with a flow rate of $3 \mathrm{~g} / \mathrm{min}$. The deposits with a thin-wall structure were fabricated at the transverse laser speed of $200 \mathrm{~mm} / \mathrm{s}, 2 \mathrm{~mm}$ laser beam size, $0.5 \mathrm{~mm}$ layer thickness, and the powers of $700 \mathrm{~W}$ for the first two layers, $600 \mathrm{~W}$ for the next two layers and $500 \mathrm{~W}$ for further layers.

Table 1. Nominal composition (atom\%) of an $\mathrm{AlCoCrFeNiTi}_{0.5}$ high-entropy alloy (HEA).

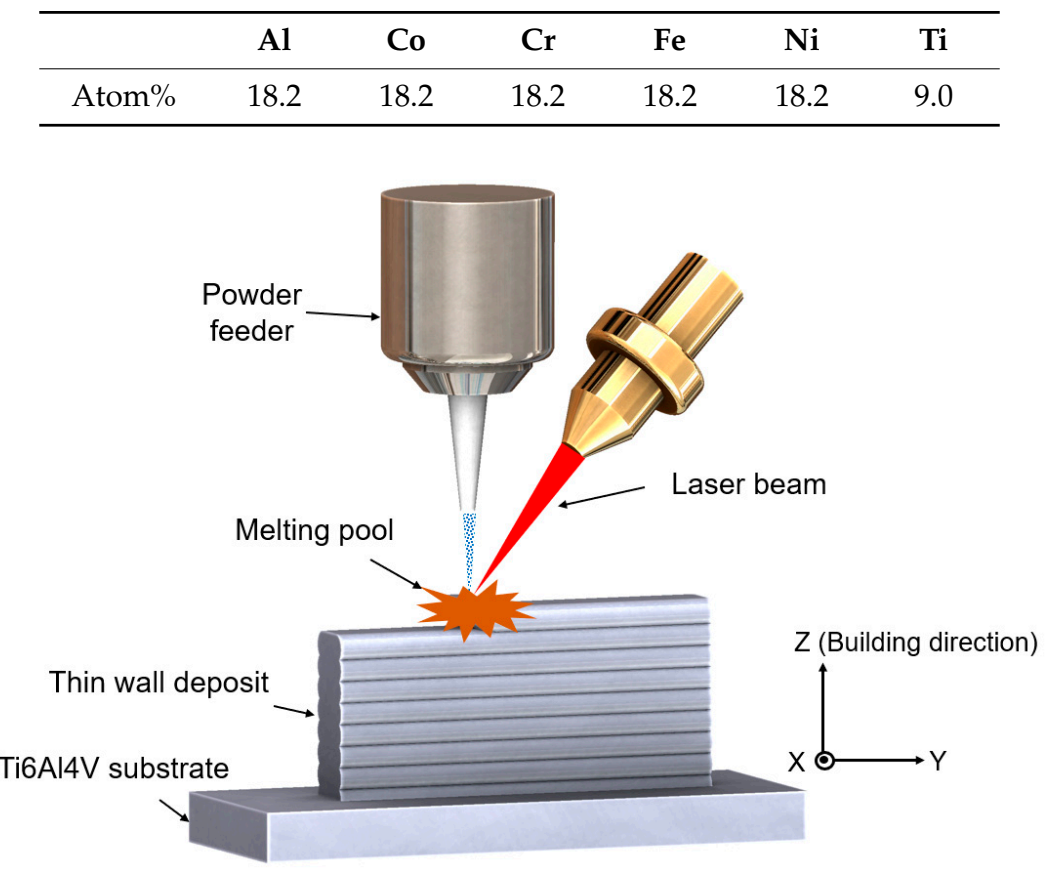

Figure 1. Schematic of the laser metal deposition (LMD) experiment setup.

\subsection{Characterization}

After the deposition, the specimens were sectioned by electrical discharge machining (EDM) (Hansvedt Industries Inc., Rantoul, IL, USA) and prepared by standard metallographic procedures. They were polished with 320-1200 grit SiC grinding paper, followed by $9 \mu \mathrm{m}, 3 \mu \mathrm{m}, 1 \mu \mathrm{m}$ diamond solutions with a final step of $0.05 \mu \mathrm{m}$ colloidal silica suspension. The HEA sample was etched with aqua regia (30 $\mathrm{mL} \mathrm{HCl}$ and $10 \mathrm{~mL} \mathrm{HNO}_{3}$ ) (Thermal Fisher Scientific, Waltham, WA, USA), and Ti6Al4V was etched with Kroll's reagent ( $2 \mathrm{~mL} \mathrm{HF,} 8 \mathrm{~mL} \mathrm{HNO}_{3}$ and $90 \mathrm{~mL} \mathrm{H}_{2} \mathrm{O}$ ) (Thermal Fisher Scientific, Waltham, WA, USA). 
The microstructure was characterized by a Helios Nanolab 600 (Thermal Fisher Scientific, Waltham, WA, USA) scanning electron microscope (SEM). The energy dispersive spectroscopy (EDS) data were collected and analyzed in the factory standardization manner (Oxford AZtec version 4.2). The electron backscatter diffraction (EBSD) scan was acquired using an Oxford HKL system with a step size of $2 \mu \mathrm{m}$, and data analysis was performed on HKL Channel 5 software (Oxford Instruments, Abingdon, UK). The grain was determined by a misorientation angle of $10^{\circ}$, and grain size was measured using the line intercept method. X-ray diffraction (XRD) profiling was performed to determine the phase constituents in the samples. The phases were identified by Phillips X'Pert diffractometer (Amsterdam, The Netherlands) using $\mathrm{Cu}-\mathrm{K} \alpha$ radiation at $45 \mathrm{kV} / 40 \mathrm{~mA}$ with a scanning step of $0.05^{\circ}$ and a scanning range from $20^{\circ}$ to $90^{\circ}$. The Vickers hardness was measured using Struers Duramin hardness equipment (Struers Inc, Cleveland, OH, USA) at a $9.8 \mathrm{~N}$ load and a duration of $10 \mathrm{~s}$. The reported hardness results were the average of ten indentations.

\subsection{Oxidation Tests}

The HEA and Ti6Al4V specimens for oxidation tests with dimensions of $10 \mathrm{~mm}$ (length) $\times 10 \mathrm{~mm}$ (width) $\times 2 \mathrm{~mm}$ (height) were prepared using EDM. Sample surfaces were subsequently polished using 320-1200 grit $\mathrm{SiC}$ grinding paper and cleaned with acetone. Oxidation tests were carried out in an electric furnace (DT-29-RSA, Deltech, Denver, CO, USA) under atmospheric pressure at $700{ }^{\circ} \mathrm{C}$ and $800^{\circ} \mathrm{C}$ for $45 \mathrm{~h}$. The samples were heated from room temperature to the target temperatures at a heating rate of $10{ }^{\circ} \mathrm{C} / \mathrm{min}$. The weight gain was measured before and after at specified intervals using an analytic balance (AG204, Mettler Toledo, Columbus, OH, USA) with an accuracy of $0.1 \mathrm{mg}$. The oxidized samples were characterized by XRD and SEM, as described above.

\section{Results and Discussion}

\subsection{Microstructures of the As-Deposited HEA}

Figure 2 illustrates the XRD patterns of as-deposited AlCoCrFeNiTi 0.5 HEA and the Ti6Al4V substrate. The $\alpha$-Ti phase was detected in the Ti6Al4V (Figure 2a). Two BCC phases were observed in the HEA (Figure 2b), and they are ordered a BCC structure (B2) phase and a disordered BCC structure (A2) phase. Through careful analysis of the standard PDF database, the two BCC phases were identified as $\mathrm{Al}-\mathrm{Ni}$ and $\mathrm{Fe}-\mathrm{Cr}$ phases, which is in accordance with the similar alloys synthesized using arc-melting [23,30] and casting [33].

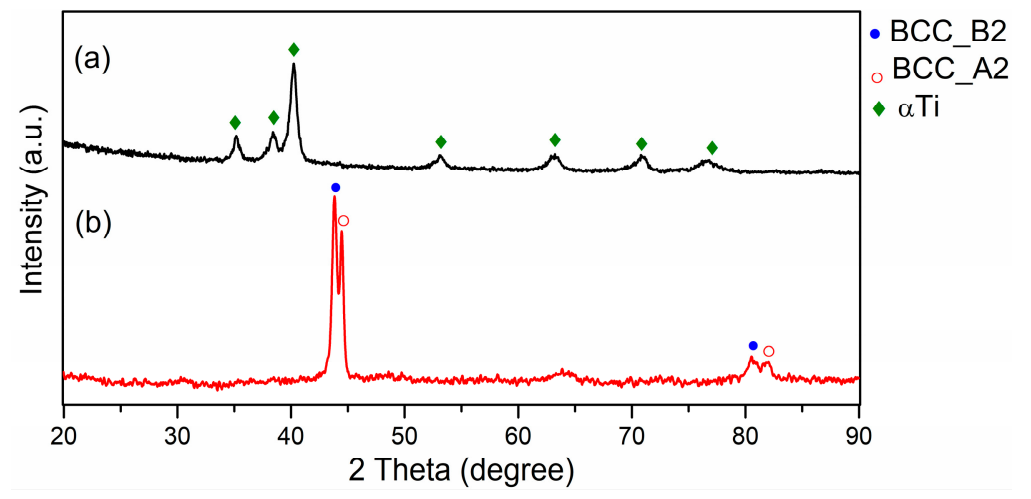

Figure 2. X-ray diffraction (XRD) pattern of the (a) Ti6Al4V substrate and (b) as-deposited $\mathrm{AlCoCrFeNiTi}_{0.5}$ HEA.

Figure 3a presents the interface between the HEA coating and the Ti6Al4V substrate, which can be seen as a good metallurgical bond without crack. The EDS line scan was used to characterize the elemental evolution from the Ti6Al4V substrate to the HEA, and the quantitative results are shown in Figure 3b. The EDS measured compositions of the Ti6Al4V substrate (Ti: $\sim 84-86$ atom\%, 
Al: $~ 10-11$ atom\%, V: 3-4 atom\%) did not deviate from the nominal compositions of Grade 5 Ti6Al4V. Since the Ti6Al4V was mixed with the HEA layer, the elements of Al ( 12-14 atom \%), Co ( 10-12 atom\%), Cr ( 11-13 atom\%), Fe ( 9-11 atom\%), Ni ( 11-14 atom\%) and Ti ( 36-39 atom\%) were detected. A small amount of $\mathrm{V}(\sim 1-3$ atom $\%)$ was detected in the HEA layer, due to the dilution. According to the equilibrium Fe- $\mathrm{V}$, Fe-Ti phase diagrams, the Fe- $\mathrm{V}$ or Fe-Ti intermetallic phases might be formed when the content of $\mathrm{V}$ was in a range of 30-65 atom\% or the content of Fe was above 50 atom\% [34-36]. From the elemental analysis above, the contents of $\mathrm{V}$ and Fe were low ( 10 atom\% or below), thus the HEA layer had a low risk of forming those intermetallic phases. Moreover, the XRD patterns obtained did not show Fe-V or Fe-Ti intermetallic phases.

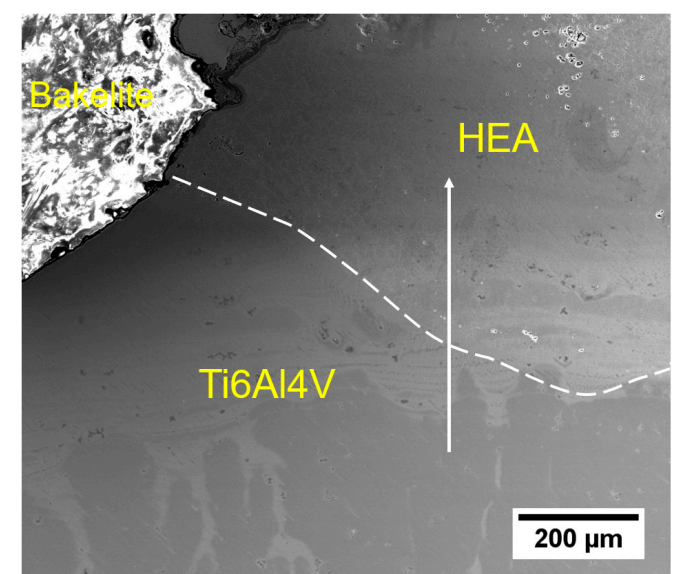

(a)

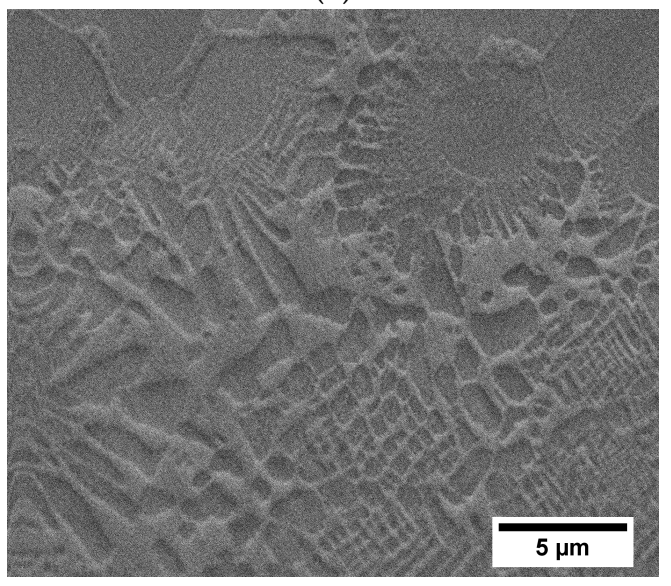

(c)

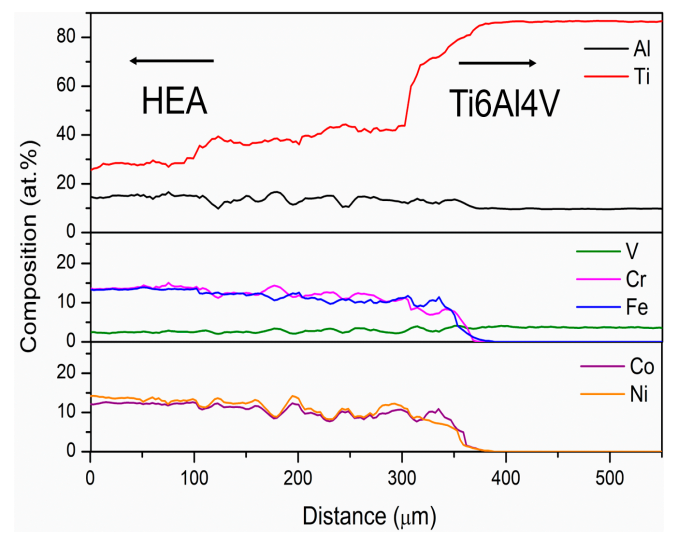

(b)

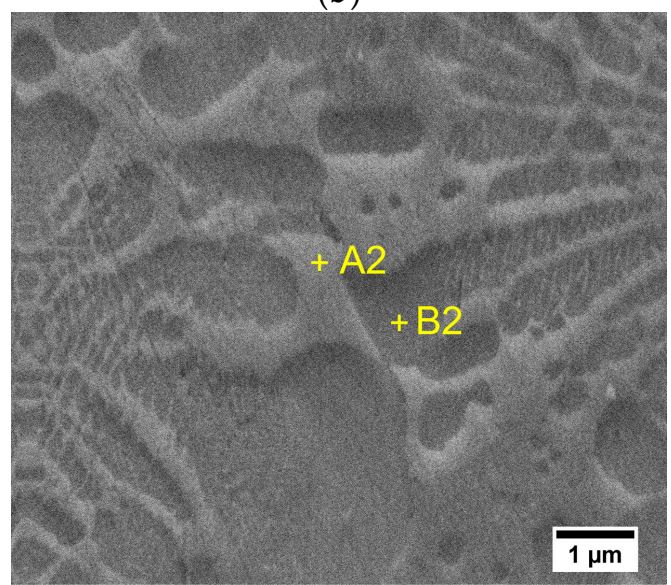

(d)

Figure 3. (a) Secondary electron images of the interface between the AlCoCrFeNiTi ${ }_{0.5}$ HEA coating and Ti6Al4V substrate, (b) energy dispersive spectroscopy (EDS) line scan along the white arrow line in (a), (c,d) backscattered electron images of the HEA microstructure at different magnifications.

The microstructural details of the laser deposited HEA at different magnifications are shown in Figure $3 c$,d. The equiaxed grains were delineated by intergranular phases (Figure 3c). The dendritic structure can be observed within the equiaxed grains. The EDS was used to analyze the element distribution, and the results are listed in Table 2 and Figure $4 \mathrm{a}-\mathrm{g}$. The dark contrast phase was enriched in $\mathrm{Al}, \mathrm{Ni}, \mathrm{Co}$, and $\mathrm{Ti}$, and the high level of $\mathrm{Fe}$ and $\mathrm{Cr}$ concentration was detected in the bright contrast phase. As learned from Table 2, the chemical compositions of Fe and $\mathrm{Cr}$ were $\sim 45$ atom $\%$ in the bright contrast phase while were $\sim 16$ atom $\%$ in the dark contrast phase. In combination with the phase identification, the dark contrasted phases rich in $\mathrm{Al}, \mathrm{Ni}$, and $\mathrm{Ti}$ are $\mathrm{B} 2$ phase while the bright contrast phases are $\mathrm{Fe}, \mathrm{Cr}$ enriched $\mathrm{A} 2$ phase. A similar microstructure has been observed, and it was attributed to the spinodal decomposition of B2 dendrites into B2 and A2 coexisting phases [20,23,37]. 
Table 2. Elemental composition (atom \%) of each phase in the HEA by SEM-EDS (more than 5 locations).

\begin{tabular}{ccccccc}
\hline \multirow{2}{*}{ Phase } & \multicolumn{7}{c}{ Element } \\
\cline { 2 - 7 } & Al & Co & Cr & Fe & Ni & Ti \\
\hline B2 & $24.8 \pm 1.6$ & $17 \pm 1.0$ & $7.2 \pm 0.7$ & $8.4 \pm 1.1$ & $21.2 \pm 0.6$ & $20 \pm 1.7$ \\
A2 & $15.5 \pm 2.1$ & $13.8 \pm 1.4$ & $19.7 \pm 1.2$ & $25.4 \pm 1.3$ & $14.3 \pm 0.9$ & $12.1 \pm 0.5$ \\
\hline
\end{tabular}

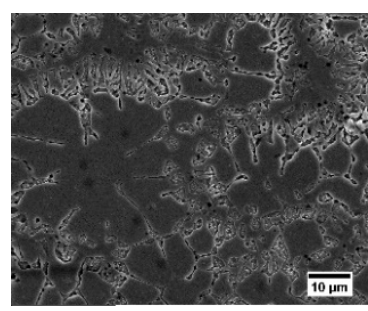

(a)

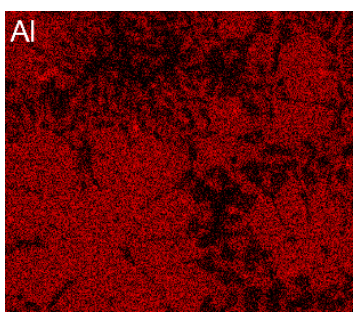

(b)

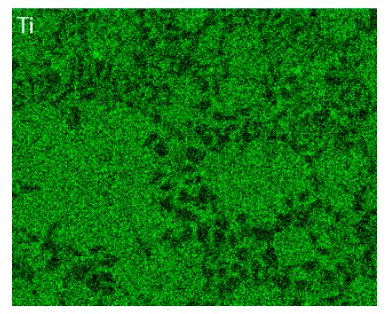

(c)

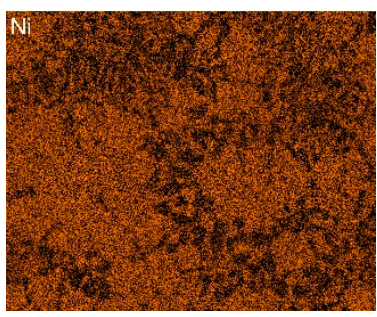

(d)

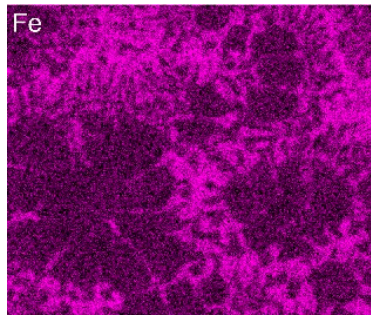

(e)

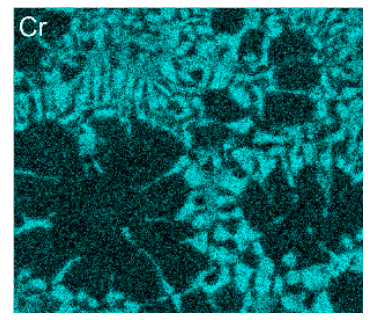

(f)

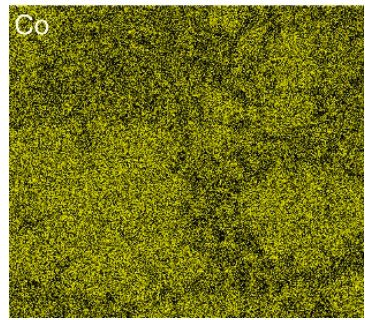

(g)

Figure 4. (a) Secondary electron image and the corresponding elemental maps of (b) $\mathrm{Al}$, (c) $\mathrm{Ti}$, (d) Ni, (e) $\mathrm{Fe},(\mathbf{f}) \mathrm{Cr}$, and (g) $\mathrm{Co}$ of the $\mathrm{AlCoCrFeNiTi}_{0.5} \mathrm{HEA}$.

The chemical mixing enthalpies of element pairs in $\mathrm{AlCoCrFeNiTi}_{0.5}$ alloy are tabulated in Table 3. The phase formation and element segregation are determined by the mixing enthalpy among the constituent metallic elements. It is shown that $\mathrm{Al}, \mathrm{Ni}$, and $\mathrm{Co}$ has high negative mixing enthalpy with $\mathrm{Ti}$, and they are liable to generate the $\mathrm{B} 2$ phase. For example, the mixing enthalpy between $\mathrm{Al}-\mathrm{Ti}, \mathrm{Al}-\mathrm{Ni}$, and $\mathrm{Al}-\mathrm{Co}$ are $-30 \mathrm{~kJ} / \mathrm{mol},-22 \mathrm{~kJ} / \mathrm{mol}$, and $-19 \mathrm{~kJ} / \mathrm{mol}$, respectively. Furthermore, $\mathrm{Cr}$ and Fe tend to form the A2 phase as they exhibit low mixing enthalpy close to zero.

Table 3. The chemical mixing enthalpies of element pairs and atomic size [19,30].

\begin{tabular}{ccccccc}
\hline Element & Al & Co & Cr & Fe & Ni & Ti \\
\hline (Atomic Size, $\mathbf{n m )}$ & $\mathbf{( 0 . 1 4 3 )}$ & $\mathbf{( 0 . 1 2 5 )}$ & $\mathbf{( 0 . 1 2 7 )}$ & $\mathbf{( 0 . 1 2 7 )}$ & $\mathbf{( 0 . 1 2 5 )}$ & $\mathbf{( 0 . 1 4 5 )}$ \\
\hline $\mathrm{Al}$ & & -19 & -10 & -11 & -22 & -30 \\
$\mathrm{Co}$ & & -4 & -1 & 0 & -28 \\
$\mathrm{Cr}$ & & & -1 & -7 & -7 \\
$\mathrm{Fe}$ & & & & -2 & -17 \\
$\mathrm{Ni}$ & & & & & -35 \\
\hline
\end{tabular}

The EBSD inverse pole figure (IPF) image of a region of $1180 \mu \mathrm{m}$ by $1056 \mu \mathrm{m}$ taken in the XZ-plane of the as-deposited $\mathrm{AlCoCrFeNiTi}_{0.5}$ alloy is given in Figure 5a. Each individual grain in the IPF image was color-coded based on the relationship between its crystallographic orientation and the building direction, which was vertically upwards ( $Z$ direction indicated in Figure $5 a$ ). There was no obvious preferred crystallographic texture developed in the alloy because the grains were randomly color-coded. It revealed the equiaxed grains from the IPF image. Moreover, the histogram of the grain size measurement is illustrated in Figure $5 \mathrm{~b}$. The grain size measured by the vertical intercept was approximately $20.3 \mu \mathrm{m}$ and was $21.1 \mu \mathrm{m}$ along with the horizontal intercept. It has been acknowledged 
that, for a specific alloy, the temperature gradient $G$ and the solidification rate $R$ determine the solidification microstructure during the laser process. As the advancing laser moved away from the substrate, the melt pool retreated, and the solidification from moved upward, which led to the temperature field to low $\mathrm{G}$ and high $\mathrm{R}$ and the formation of the equiaxed grains. A recent study demonstrated that B2-structured dendrites were frequently fragmented, providing profuse effective nucleation sites, and therefore, promoted equiaxed grain formation in the AlCoCrFeNiTi ${ }_{0.5} \mathrm{HEA}_{\text {[37] }}$
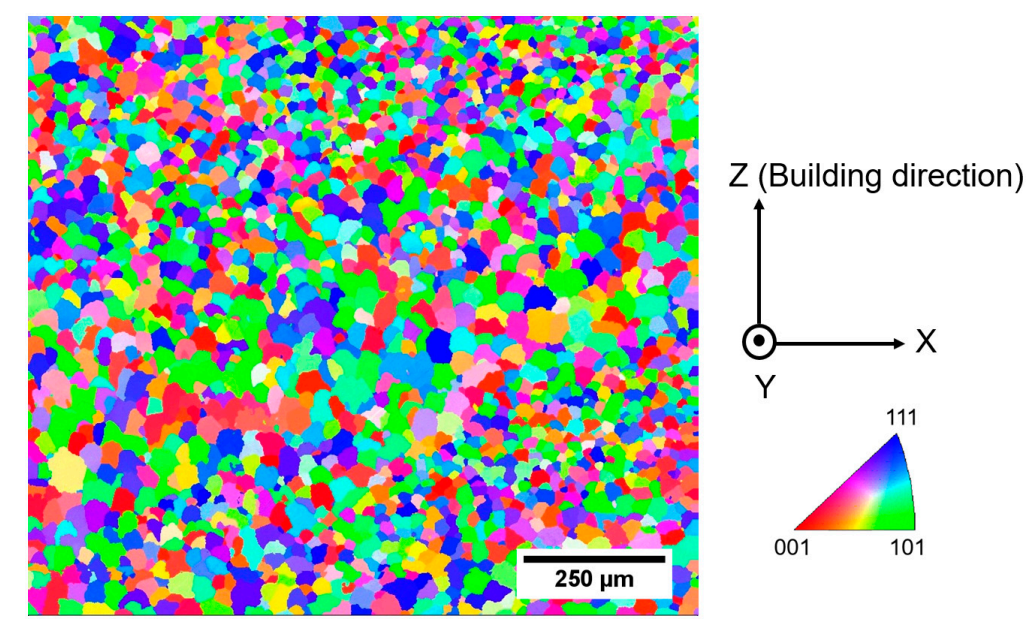

(a)

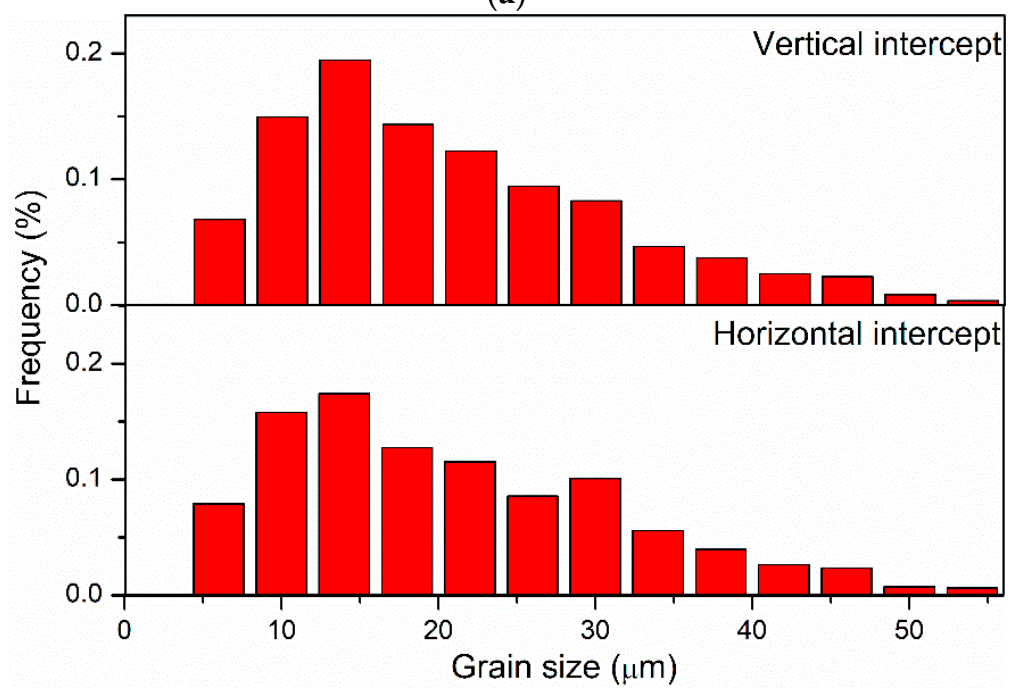

(b)

Figure 5. (a) Electron backscatter diffraction (EBSD)-inverse pole figure (IPF) map of the XZ-plane in the as-deposited HEA sample, and (b) histogram of the grain size measurement.

Figure 6 presents the microhardness of $\mathrm{AlCoCrFeNiTi}_{0.5}$ (Al1.0Ti0.5) HEA and Ti6Al4V (Ti64) substrate. Those of $\mathrm{AlCoCrFeNi}(\mathrm{Al1} .0), \mathrm{CrCuFeNi}_{2}(\mathrm{Al0}), \mathrm{Al}_{0.75} \mathrm{CrCuFeNi}_{2}$ (Al0.75), and AISI 304 stainless steel substrate (304 SS) alloys reported in our previous work are shown for comparison $[17,18]$. The addition of Ti into the AlCoCrFeNi system enhanced the microhardness from $418 \mathrm{HV}$ (Al1.0) to $634 \mathrm{HV}$ (Al1.0Ti0.5), which was about 2.1 times that of the Ti6Al4V substrate. Since Ti has a larger atomic radius than $\mathrm{Al}$ (as in Table 3), it would increase lattice distortion and improve the effect of solid solution strengthening. Our previous study reported that Al0 and Al0.75 possessed FCC phase structures, making them less resistant towards localized plastic deformation, thereby exhibiting low hardness (170 HV and $290 \mathrm{HV}$, respectively). The BCC phase consisted of a decreased number of dislocation slip systems compared to the FCC phase, which could explain the high hardness of $\mathrm{AlCoCrFeNiTi}_{0.5}$ HEA in this work. 


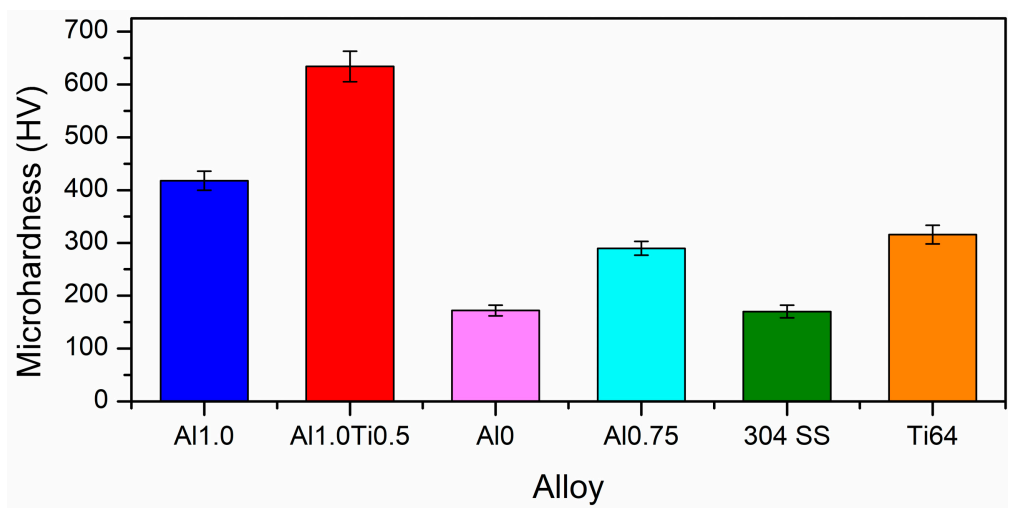

Figure 6. Microhardness of various alloys $[17,18]$.

\subsection{Oxidation Behavior}

\subsubsection{Oxidation Kinetics}

Figure 7 displays the isothermal oxidation results of the $\mathrm{AlCoCrFeNiTi}{ }_{0.5} \mathrm{HEA}$ and $\mathrm{Ti}$ Al4V at different temperatures $\left(700{ }^{\circ} \mathrm{C}\right.$ and $\left.800{ }^{\circ} \mathrm{C}\right)$, over a period of $45 \mathrm{~h}$ in the air atmosphere. As illustrated in Figure $7 \mathrm{a}$, the weight gains $(\Delta W)$ of the HEA were found to be $0.23 \mathrm{mg} / \mathrm{cm}^{2}$ and $0.61 \mathrm{mg} / \mathrm{cm}^{2}$ at $700{ }^{\circ} \mathrm{C}$ and $800{ }^{\circ} \mathrm{C}$, respectively. For the Ti6Al4V alloy, its mass gain was measured at $5.87 \mathrm{mg} / \mathrm{cm}^{2}$ at $700{ }^{\circ} \mathrm{C}$, and its curve was recorded only within $20 \mathrm{~h}$ due to the scale spalling at $800{ }^{\circ} \mathrm{C}$. The oxidation curves were observed to follow the parabolic form. The results of the parabolic rate law plot are shown in Figure $7 b-d$. Here, the parabolic rate constant, $K_{p}$ can be considered as a measure of the oxidation resistance, and it was calculated using the Equation (1).

$$
\left(\frac{\Delta W}{A}\right)^{2}=K_{p} \times t+C
$$

where $\Delta W$ is the mass gain $\left(\mathrm{mg} / \mathrm{cm}^{2}\right)$, A represents the unit area, $K_{p}$ is the parabolic rate constant in $\mathrm{mg}^{2} \mathrm{~cm}^{-4} \mathrm{~h}^{-1}, \mathrm{t}$ is the oxidation time $(\mathrm{h})$, and $\mathrm{C}$ is a constant value. In addition, the coefficient determination $\mathrm{R}^{2}$ values (>0.95) indicate that the parabolic model fits well with the observations in Figure $7 \mathrm{~b}-\mathrm{d}$. The $K_{p}$ values were determined as $0.8501\left(\mathrm{Ti6A} 4 \mathrm{~V}\right.$ at $\left.700{ }^{\circ} \mathrm{C}\right), 0.0011\left(\mathrm{HEA}\right.$ at $700{ }^{\circ} \mathrm{C}$ ) and $0.0077 \mathrm{mg}^{2} \mathrm{~cm}^{-4} \mathrm{~h}^{-1}\left(\mathrm{HEA}\right.$ at $\left.800^{\circ} \mathrm{C}\right)$. For discussion in Section 3.3, the $K_{p}$ values were converted to the unit of $\mathrm{g}^{2} \mathrm{~cm}^{-4} \mathrm{~s}^{-1}$, i.e., $2.36 \times 10^{-10}$ (Ti6Al4V at $700^{\circ} \mathrm{C}$ ), $3.06 \times 10^{-13}\left(\mathrm{HEA}\right.$ at $\left.700{ }^{\circ} \mathrm{C}\right)$, and $2.14 \times 10^{-12}$ $\left(\right.$ HEA at $\left.800^{\circ} \mathrm{C}\right)$. Hence, better oxidation resistance was observed with the HEA as its low weight gain and parabolic rate constant.

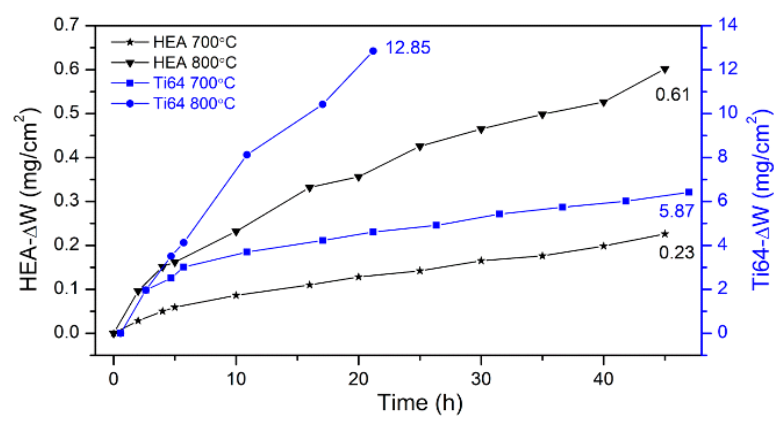

(a)

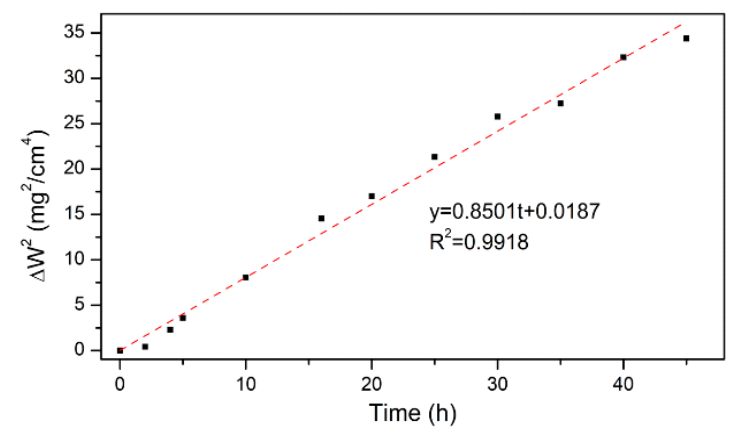

(b)

Figure 7. Cont. 


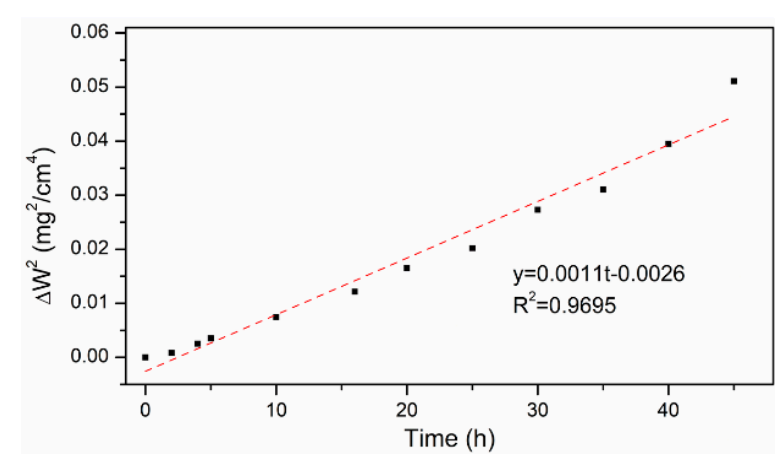

(c)

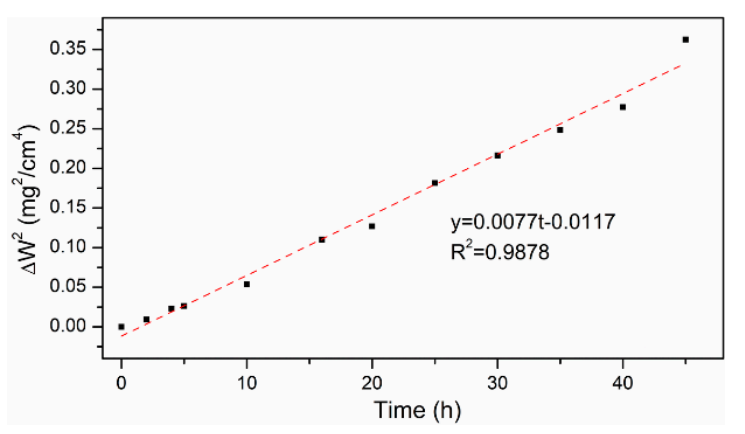

(d)

Figure 7. Isothermal oxidation results of $\mathrm{AlCoCrFeNiTi}_{0.5} \mathrm{HEA}$ and $\mathrm{Ti} 6 \mathrm{Al} 4 \mathrm{~V}$ at $700{ }^{\circ} \mathrm{C}$ and $800{ }^{\circ} \mathrm{C}$ for $45 \mathrm{~h}$; (a) weight gain versus oxidation time curves, the parabolic plot for (b)Ti6Al4V at $700{ }^{\circ} \mathrm{C}$, (c) HEA at $700{ }^{\circ} \mathrm{C}$ and (d) $\mathrm{HEA}$ at $800{ }^{\circ} \mathrm{C}$.

\subsubsection{Phase Analysis}

XRD analyses were performed following oxidation tests, and the results are indicated in Figure 8. The strong diffraction peaks of $\mathrm{TiO}_{2}$ and weak diffraction peaks of $\mathrm{Al}_{2} \mathrm{O}_{3}$ were seen from the Ti6Al4V substrate, as in Figure 8a. This illustrated that the scale formed on the Ti6Al4V substrate was mostly composed of $\mathrm{TiO}_{2}$ and a small amount of $\mathrm{Al}_{2} \mathrm{O}_{3}$. The $\mathrm{TiO}_{2}$ was a poorly adherent and brittle scale, and $\mathrm{Ti}$ and $\mathrm{O}$ ions could diffuse through the porous oxides, which resulted in the fast oxidation kinetics. A thick oxide scale was formed and cracked due to the thermal stress at the elevated temperature [2].

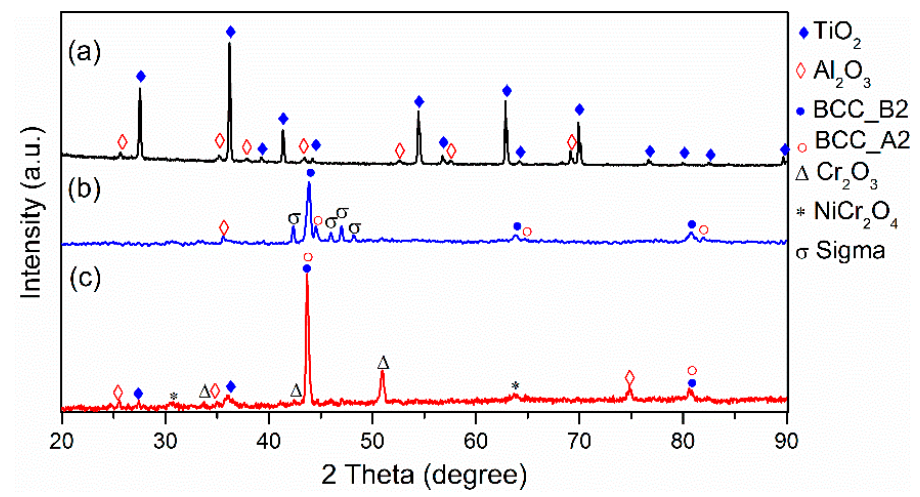

Figure 8. XRD patterns of the oxidized (a) Ti6Al4V at $700{ }^{\circ} \mathrm{C}$, (b) HEA at $700{ }^{\circ} \mathrm{C}$, and (c) HEA at $800{ }^{\circ} \mathrm{C}$ for $45 \mathrm{~h}$.

For the $\mathrm{AlCoCrFeNiTi}{ }_{0.5}$ alloy oxidized at $700{ }^{\circ} \mathrm{C}, \mathrm{Al}_{2} \mathrm{O}_{3}$, together with $\mathrm{B} 2$ and $\mathrm{A} 2$ phases were detected, as shown in Figure $8 \mathrm{~b}$. When oxidized at $800{ }^{\circ} \mathrm{C}$, the oxides were $\mathrm{Cr}_{2} \mathrm{O}_{3}, \mathrm{TiO}_{2}, \mathrm{Al}_{2} \mathrm{O}_{3}$, and spinel (mainly composed of $\mathrm{NiCr}_{2} \mathrm{O}_{4}$ ), as in Figure 8c. Besides, a Fe-Cr sigma phase with a tetragonal structure $\left(\mathrm{P}_{2} / \mathrm{mmm}, 136\right)$ was detected in $\mathrm{AlCoCrFeNiTi}_{0.5}$ alloy oxidized shown in Figure $8 \mathrm{~b}$. A similar phenomenon was described by Wang et al., in which the transformation occurred from $\mathrm{BCC}$ to sigma phase at $650{ }^{\circ} \mathrm{C}[38,39]$.

\subsubsection{Cross-Sectional Morphology of Oxide Scales}

The cross-sectional backscattered electron images and the elemental composition distribution of the Ti6Al4V and $\mathrm{AlCoCrFeNiTi}{ }_{0.5} \mathrm{HEA}$ oxidized at $700{ }^{\circ} \mathrm{C}$ and $800{ }^{\circ} \mathrm{C}$ are present in Figure 9. The oxide scales of the Ti6Al4V had a thickness of $25.54 \pm 1.85 \mu \mathrm{m}$ and they were loose, porous, and some cracks can be observed in Figure 9a. Its main composition was $\mathrm{TiO}_{2}$, as the content of $\mathrm{Ti}$ was $\sim 25-28$ atom\% and $\sim 47-60$ atom $\%$ of $\mathrm{O}$ (as in Figure $9 \mathrm{~b}$ ). EDS mapping analysis of the cross-sectional HEA oxidized at $700{ }^{\circ} \mathrm{C}$ and $800{ }^{\circ} \mathrm{C}$ was performed to reveal the oxide scales better, and the results are shown in 
Figure 10a-h and Figure 11a-h. The thickness of the scale on the HEA oxidized at $700{ }^{\circ} \mathrm{C}$ was about $1.73 \pm 0.14 \mu \mathrm{m}$, of which it mainly contained $\mathrm{Al}_{2} \mathrm{O}_{3}$ (Al: $\sim 15-17$ atom\%, O: 50-55 atom\%, Ni, Cr, Co, Ti: below 10 atom $\%$ as in Figure 9c,d and this was consistent with the observation in Figure 10. The thickness of the scale on the HEA reached to $5.12 \pm 0.37 \mu \mathrm{m}$ at $800{ }^{\circ} \mathrm{C}$ in Figure 9e, corresponding to that the scale thickness increased with the oxidation temperature. The scale structure mainly comprised of $\mathrm{TiO}_{2}$ (Ti: $\sim 20-22$ atom\%, O: $\sim 63-66$ atom\%), $\mathrm{Cr}_{2} \mathrm{O}_{3}$ (Cr: $\sim 18-21$ atom\%, O: $\sim 53-56$ atom\%) and $\mathrm{Al}_{2} \mathrm{O}_{3}$ (Al: $\sim 17-19$ atom\%, O: 48-50 atom\%) for the oxidized HEA at $800{ }^{\circ} \mathrm{C}$ (Figure $9 \mathrm{f}$ ). The thickness of each layer was measured at $0.96 \mu \mathrm{m}$ for the $\mathrm{TiO}_{2}, 1.69 \mu \mathrm{m}$ for the $\mathrm{Cr}_{2} \mathrm{O}_{3}$, and $2.51 \mu \mathrm{m}$ for the $\mathrm{Al}_{2} \mathrm{O}_{3}$. This HEA mainly formed an outermost $\mathrm{TiO}_{2}$ scale, an innermost continuous $\mathrm{Al}_{2} \mathrm{O}_{3}$ layer, and a $\mathrm{Cr}_{2} \mathrm{O}_{3}$ layer in-between, as illustrated in Figure 11a-e. The formation of the continuous $\mathrm{Cr}_{2} \mathrm{O}_{3}$ and $\mathrm{Al}_{2} \mathrm{O}_{3}$ layers can actually limit the diffusion of oxygen [40], providing excellent oxidation resistance at high temperatures.

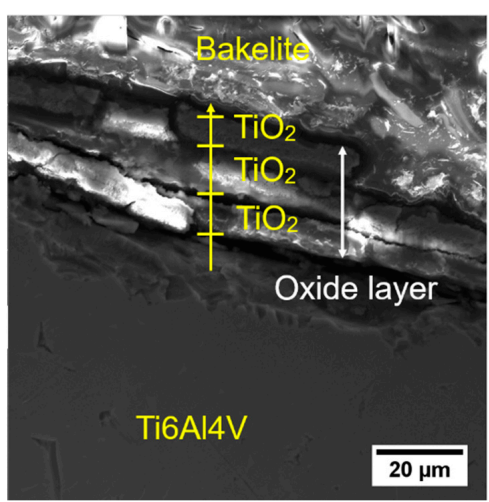

(a)

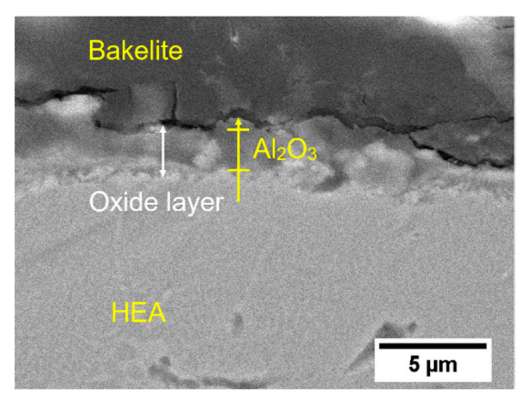

(c)

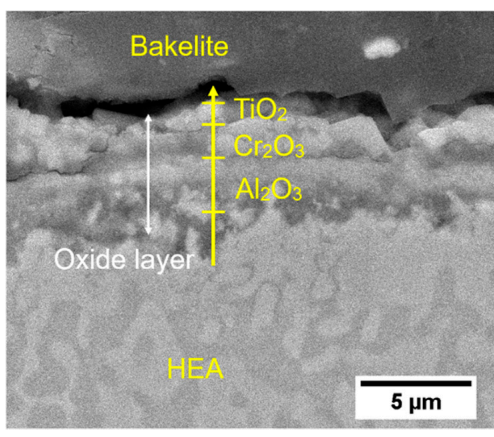

(e)

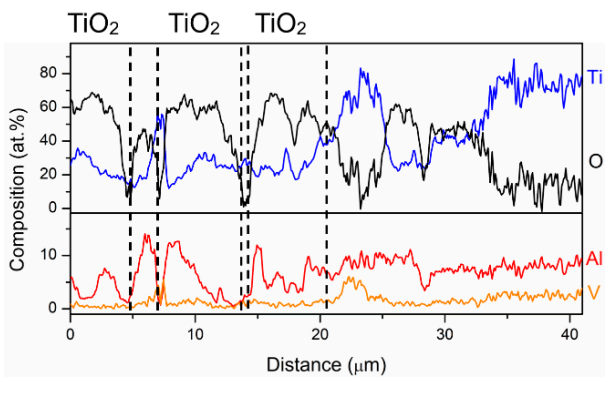

(b)

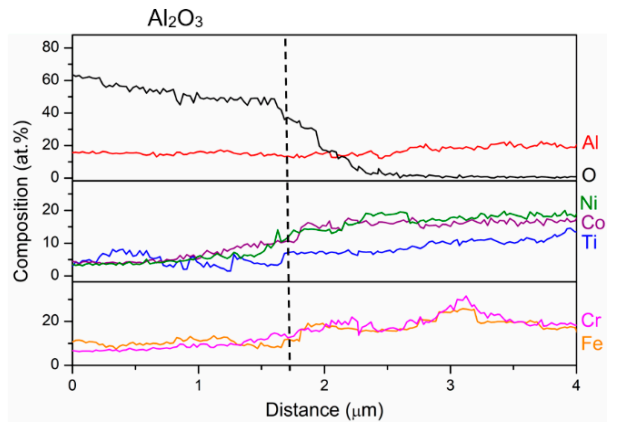

(d)

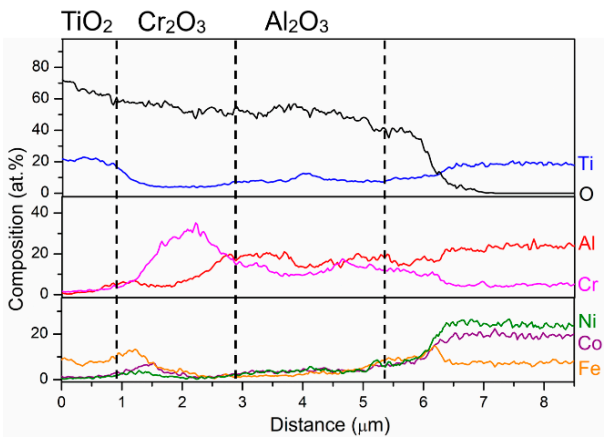

(f)

Figure 9. Cross-sectional backscattered electron images and the corresponding elemental composition distribution along the yellow arrow for the oxidized: (a) and (b) Ti6Al4V at $700{ }^{\circ} \mathrm{C}$, (c) and (d) HEA at $700{ }^{\circ} \mathrm{C},(\mathbf{e})$ and (f) HEA at $800^{\circ} \mathrm{C}$ for $45 \mathrm{~h}$. 


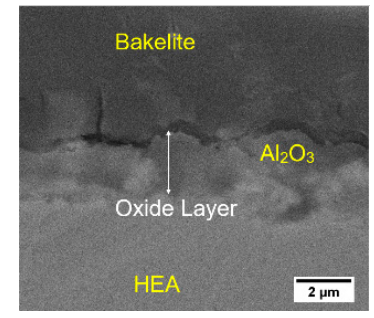

(a)

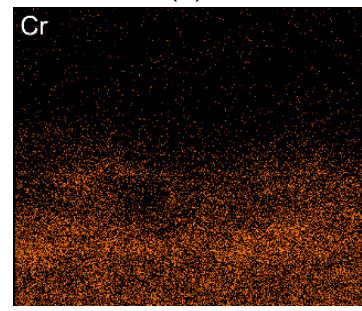

(e)

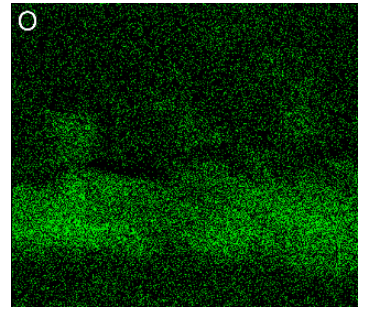

(b)

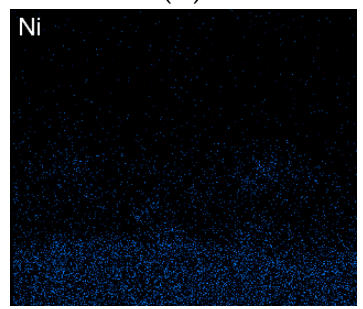

(f)

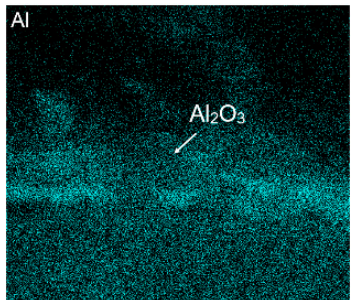

(c)

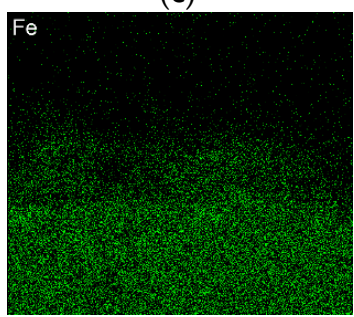

(g)

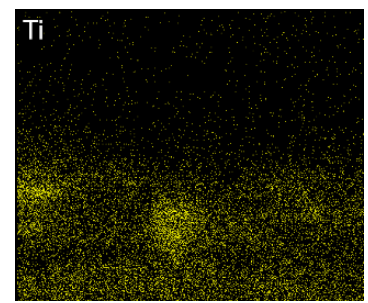

(d)

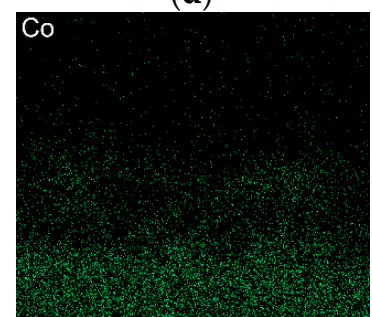

(h)

Figure 10. (a) Backscattered electron image and the corresponding (b) $\mathrm{O},(\mathbf{c}) \mathrm{Al}$, (d) $\mathrm{Ti}$, (e) $\mathrm{Cr}$, (f) $\mathrm{Ni}$, (g) Fe and (h) Co EDS maps of the oxide scales on $\mathrm{AlCoCrFeNiTi}{ }_{0.5}$ HEA oxidized at $700{ }^{\circ} \mathrm{C}$ for $45 \mathrm{~h}$.

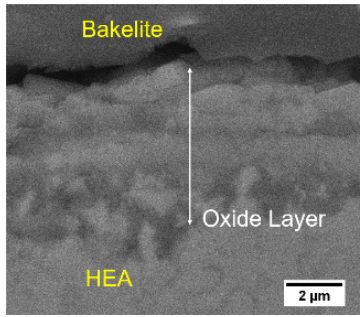

(a)

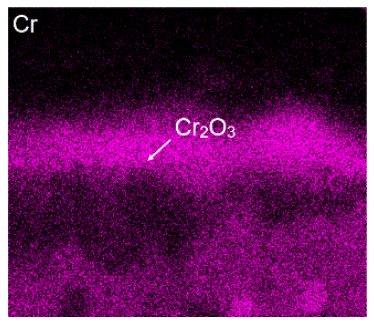

(e)

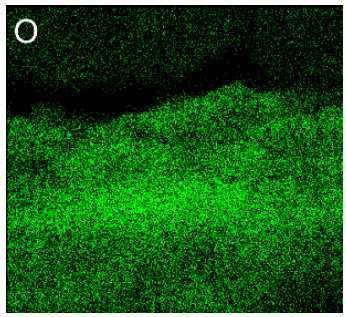

(b)

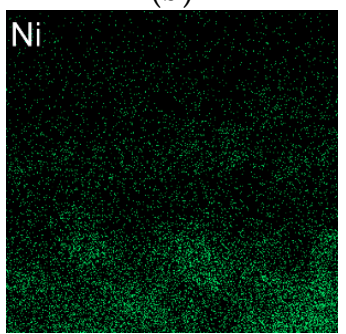

(f)

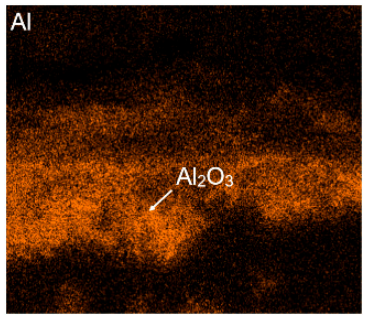

(c)

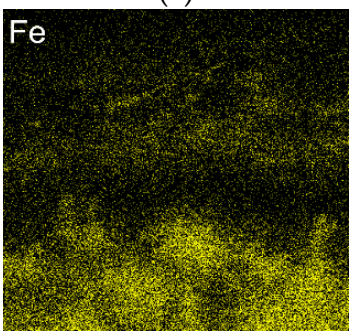

(g)

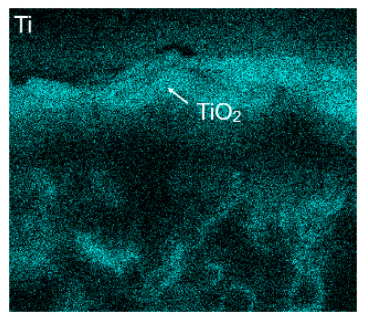

(d)

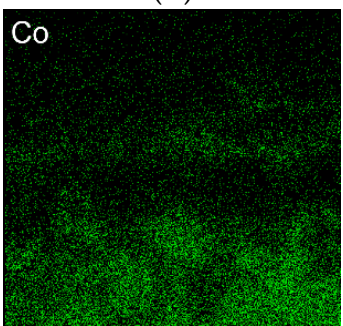

(h)

Figure 11. (a) Backscattered electron image and the corresponding (b) $\mathrm{O},(\mathbf{c}) \mathrm{Al}$, (d) $\mathrm{Ti},(\mathbf{e}) \mathrm{Cr}$, (f) $\mathrm{Ni}$, (g) Fe and (h) Co EDS maps of the oxide scales on AlCoCrFeNiTi 0.5 HEA oxidized at $800{ }^{\circ} \mathrm{C}$ for $45 \mathrm{~h}$.

\subsection{Discussion on the Oxidation Behavior}

The oxidation mechanism of $\mathrm{Ti} 6 \mathrm{Al} 4 \mathrm{~V}$ and $\mathrm{AlCoCrFeNiTi}_{0.5}$ HEA can be obtained from the above analysis. The predominant oxide in $\mathrm{Ti} 6 \mathrm{Al} 4 \mathrm{~V}$ is $\mathrm{TiO}_{2}$, with a small amount of $\mathrm{Al}_{2} \mathrm{O}_{3}$ at $700{ }^{\circ} \mathrm{C}$. Since $\mathrm{TiO}_{2}$ is brittle and loose in the oxide film, it is vulnerable to detach from the substrate when it comes to high-temperature oxidation. For the $\mathrm{AlCoCrFeNiTi}_{0.5} \mathrm{HEA}$, it is slightly oxidized at $700{ }^{\circ} \mathrm{C}$, as a thin $\mathrm{Al}_{2} \mathrm{O}_{3}$ oxide layer is observed, and the Fe-Cr sigma phase occurs due to the phase transformation. The Al, $\mathrm{Cr}$, and $\mathrm{Ti}$ are selectively oxidized and diffuses and enriches into the oxide layer at $800{ }^{\circ} \mathrm{C}$. The $\mathrm{TiO}_{2}$ is distributed in the outermost oxide layer, and continuous protective $\mathrm{Cr}_{2} \mathrm{O}_{3}$ and $\mathrm{Al}_{2} \mathrm{O}_{3} \mathrm{scales}$ are located beneath the $\mathrm{TiO}_{2}$ layer. The behavior of the $\mathrm{AlCoCrFeNiTi}{ }_{0.5} \mathrm{HEA}$ is similar to Group II in $\mathrm{Ni}-\mathrm{Cr}-\mathrm{Al}$ alloy systems $[25,41]$. The oxide map can be explained that the concentrations of $\mathrm{Al}$ and $\mathrm{Cr}$ facilitate the external $\mathrm{Cr}_{2} \mathrm{O}_{3}$ with an internal subscale $\mathrm{Al}_{2} \mathrm{O}_{3}$ scale. In a review of thermodynamic data, the standard Gibbs free energy of $\mathrm{Al}_{2} \mathrm{O}_{3}\left(-891 \mathrm{KJ} / \mathrm{mol}\right.$ at $\left.800{ }^{\circ} \mathrm{C}\right)$ formation is more negative than other 
possible oxides (i.e., $\mathrm{Cr}_{2} \mathrm{O}_{3}:-569 \mathrm{KJ} / \mathrm{mol}$ ) in the HEA [42], the growth of $\mathrm{Al}_{2} \mathrm{O}_{3}$ should be favorable during the initial stage of oxidation.

It is important and interesting to compare the oxidation rates from our work with other HEAs and conventional alloys. Table 4 collects the parabolic constants $K_{p}$ measured for different HEAs (CrMnFeCoNi, $\mathrm{FeCoNiCrAl}$ and $\mathrm{Al}_{0.5} \mathrm{CoCrFeNiTi}_{0.5}$ ) and alumina-forming austenitic (AFA) stainless steel. It is worth noting that the examined HEAs are comparable to those similar types of HEAs. The $\mathrm{AlCoCrFeNiTi}_{0.5}$ HEA is believed to own good oxidation properties due to the sluggish diffusion effect and formation of $\mathrm{Al}_{2} \mathrm{O}_{3}$ and $\mathrm{Cr}_{2} \mathrm{O}_{3}$ oxides. However, its oxidation resistance is shown to fall short of $\mathrm{FeCoNiCrAl}, \mathrm{Al}_{1.5} \mathrm{CoCrFeNiTi}_{0.5}$ and AFA steel, i.e., $2-3$ order of differences in $K_{p}$ values. According to Butler et al. [24,25], increased $\mathrm{Al}$ content enhanced the continuity of the $\mathrm{Al}_{2} \mathrm{O}_{3}$ scale, leading to improved oxidation resistance. The formed alumina could exhibit a protective effect at low Ti content. With the addition of Ti, it negatively affected the oxidation behavior of the aluminum-containing HEAs. As described in Erdogan's work [43], a good barrier against oxidation did not form in the Ti-rich $\mathrm{CoCrFeNiAl}_{0.5} \mathrm{Ti}$ due to the fast-growing oxides.

Table 4. The values of the parabolic constants for various alloys.

\begin{tabular}{|c|c|c|c|}
\hline Alloy & $K_{p}\left(g^{2} \mathrm{mg}^{-4} \mathrm{~s}^{-1}\right)$ & Temperature $\left({ }^{\circ} \mathrm{C}\right)$ & Reference \\
\hline \multirow{2}{*}{$\mathrm{AlCoCrFeNiTi}_{0.5}$} & $3.06 \times 10^{-13}$ & 700 & \multirow{2}{*}{ This work } \\
\hline & $2.14 \times 10^{-12}$ & 800 & \\
\hline \multirow{2}{*}{ CrMnFeCoNi } & $5.47 \times 10^{-12}$ & 700 & \multirow{2}{*}{ [44] } \\
\hline & $1.67 \times 10^{-11}$ & 800 & \\
\hline \multirow{2}{*}{ FeCoNiCrAl } & $8.5 \times 10^{-15}$ & 700 & \multirow{2}{*}{ [45] } \\
\hline & $4.0 \times 10^{-14}$ & 800 & \\
\hline $\mathrm{Al}_{1.5} \mathrm{CoCrFeNiTi}{ }_{0.5}$ & $1.66 \times 10^{-14}$ & 700 & {$[46]$} \\
\hline 14Cr-25Ni-3.5Al AFA steel & $3 \times 10^{-14}$ & 850 & [47] \\
\hline \multirow{2}{*}{ 22Cr-25Ni-2.5Al AFA steel } & $9.19 \times 10^{-15}$ & 700 & \multirow{2}{*}[48]{} \\
\hline & $3.55 \times 10^{-14}$ & 800 & \\
\hline
\end{tabular}

Based on these facts, the laser processed $\mathrm{AlCoCrFeNiTi}_{0.5}$ HEA has great potential under the high-temperature application. A great effort should be put on (1) the investigation of the sequence of oxide formation at the early stage, and (2) the improvement of the oxidation resistance by alloying addition, e.g., Al, Si.

\section{Conclusions}

The AlCoCrFeNiTi ${ }_{0.5}$ high-entropy alloy (HEA) coating was fabricated by laser metal deposition (LMD) on a Ti6Al4V substrate. The microstructure and isothermal oxidation behavior at $700{ }^{\circ} \mathrm{C}$ and $800^{\circ} \mathrm{C}$ in air atmosphere were investigated, and the underlying mechanisms were discussed. The main phase constitutions in as-deposited HEA were the $\mathrm{Fe}, \mathrm{Cr}$-rich $\mathrm{A} 2$ and $\mathrm{Al}, \mathrm{Ni}$, and Ti-enriched $\mathrm{B} 2$ phases. The isothermal oxidation testing demonstrated that the HEA coatings could effectively improve the oxidation resistance of the Ti6Al4V substrate. The oxidation kinetics of the HEA and Ti6Al4V met the parabolic rate law, while the weight gain and parabolic rate constant of the HEA were lower than Ti6Al4V, implying a better oxidation resistance. The scales of the Ti6Al4V were mainly composed of $\mathrm{TiO}_{2}$ at $700{ }^{\circ} \mathrm{C}$, and it suffered from spalling at $800^{\circ} \mathrm{C}$. The $\mathrm{AlCoCrFeNiTi}{ }_{0.5} \mathrm{HEA}$ was slightly oxidized at $700{ }^{\circ} \mathrm{C}$ as a few oxides were formed. At $800^{\circ} \mathrm{C}$, the formation of continuous $\mathrm{Al}_{2} \mathrm{O}_{3}, \mathrm{Cr}_{2} \mathrm{O}_{3}$ scales could be ascribed to their good oxidation resistance of the HEA. This work provides an approach to enhance the oxidation resistance of Ti6Al4V alloy and accelerate the broad adoption of HEAs in high-temperature applications. 
Author Contributions: W.C. designed, conducted the experiment, and wrote the manuscript; W.-T.C. and W.L. assisted in results analysis; W.-T.C. assisted in SEM imaging; F.L. supervised the research project. The authors reviewed the manuscript. All authors have read and agreed to the published version of the manuscript.

Funding: Wenyuan Cui and Frank Liou are grateful for the financial support from NSF (National Science Foundation) grants CMMI-1625736 and EEC-1937128, and Intelligent System Center (ISC) at Missouri University of Science and Technology (Missouri S\&T).

Acknowledgments: The materials preparation and characterization were supported by the Materials Research Center (MRC) at Missouri S\&T. Wenyuan Cui would like to thank Jiaqi Duan, Austin J. Martin, and Eric Bohannan from Missouri S\&T for their support and discussions.

Conflicts of Interest: The authors declare no conflict of interest.

\section{References}

1. Guleryuz, H.; Cimenoglu, H. Oxidation of Ti-6Al-4V alloy. J. Alloy. Compd. 2009, 472, 241-246. [CrossRef]

2. Huang, C.; Zhang, Y.; Shen, J.; Vilar, R. Thermal stability and oxidation resistance of laser clad TiVCrAlSi high entropy alloy coatings on Ti-6Al-4V alloy. Surf. Coat. Technol. 2011, 206, 1389-1395. [CrossRef]

3. Weng, F.; Chen, C.; Yu, H. Research status of laser cladding on titanium and its alloys: A review. Mater. Des. 2014, 58, 412-425. [CrossRef]

4. Lv, Y.H.; Li, J.; Tao, Y.F.; Hu, L.F. High-temperature wear and oxidation behaviors of TiNi/Ti 2 Ni matrix composite coatings with TaC addition prepared on Ti6Al4V by laser cladding. Appl. Surf. Sci. 2017, 402, 478-494. [CrossRef]

5. Kumar, S.; Sankara Narayanan, T.S.N.; Ganesh Sundara Raman, S.; Seshadri, S.K. Thermal oxidation of Ti6Al4V alloy: Microstructural and electrochemical characterization. Mater. Chem. Phys. 2010, 119, 337-346. [CrossRef]

6. Zhou, Z.Y.; Liu, X.B.; Zhuang, S.G.; Wang, M.; Luo, Y.S.; Tu, R.; Zhou, S.F. Laser in-situ synthesizing Ti5Si3/Al3Ni2 reinforced Al3Ti/NiTi composite coatings: Microstructure, mechanical characteristics and oxidation behavior. Opt. Laser Technol. 2019, 109, 99-109. [CrossRef]

7. Bobbio, L.D.; Otis, R.A.; Borgonia, J.P.; Dillon, R.P.; Shapiro, A.A.; Liu, Z.K.; Beese, A.M. Additive manufacturing of a functionally graded material from Ti-6Al-4V to Invar: Experimental characterization and thermodynamic calculations. Acta Mater. 2017, 127, 133-142. [CrossRef]

8. Reichardt, A.; Dillon, R.P.; Borgonia, J.P.; Shapiro, A.A.; McEnerney, B.W.; Momose, T.; Hosemann, P. Development and characterization of Ti-6Al-4V to 304L stainless steel gradient components fabricated with laser deposition additive manufacturing. Mater. Des. 2016, 104, 404-413. [CrossRef]

9. Li, W.; Ghazanfari, A.; McMillen, D.; Leu, M.C.; Hilmas, G.E.; Watts, J. Characterization of zirconia specimens fabricated by ceramic on-demand extrusion. Ceram. Int. 2018, 44, 12245-12252. [CrossRef]

10. Li, W.; Ghazanfari, A.; McMillen, D.; Leu, M.C.; Hilmas, G.E.; Watts, J. Fabricating ceramic components with water dissolvable support structures by the Ceramic On-Demand Extrusion process. CIRP Ann. Manuf. Technol. 2017, 66, 225-228. [CrossRef]

11. Cui, W.; Zhang, Y.; Zhang, X.; Li, L.; Liou, F. Metal Additive Manufacturing Parts Inspection Using Convolutional Neural Network. Appl. Sci. 2020, 10, 545. [CrossRef]

12. Liu, H.; Zhang, X.; Jiang, Y.; Zhou, R. Microstructure and high temperature oxidation resistance of in-situ synthesized TiN/Ti3Al intermetallic composite coatings on Ti6Al4V alloy by laser cladding process. J. Alloy. Compd. 2016, 670, 268-274. [CrossRef]

13. Zambrano Carrullo, J.C.; Pereira Falcón, J.C.; Amigó Borrás, V. Influence of process parameters and initial microstructure on the oxidation resistance of Ti48A12Cr2Nb coating obtained by laser metal deposition. Surf. Coat. Technol. 2019, 358, 114-124. [CrossRef]

14. Liu, F.; Mao, Y.; Lin, X.; Zhou, B.; Qian, T. Microstructure and high temperature oxidation resistance of Ti-Ni gradient coating on TA2 titanium alloy fabricated by laser cladding. Opt. Laser Technol. 2016, 83, 140-147. [CrossRef]

15. Liu, X.B.; Wang, H.M. Microstructure, wear and high-temperature oxidation resistance of laser clad Ti5Si3/ $/$ TiSi composite coatings on $\gamma$-TiAl intermetallic alloy. Surf. Coat. Technol. 2006, 200, 4462-4470. [CrossRef] 
16. Yeh, J.-W.; Chen, S.-K.; Lin, S.-J.; Gan, J.-Y.; Chin, T.-S.; Shun, T.-T.; Tsau, C.-H.; Chang, S.-Y. Nanostructured High-Entropy Alloys with Multiple Principal Elements: Novel Alloy Design Concepts and Outcomes. Adv. Eng. Mater. 2004, 6, 299-303. [CrossRef]

17. Cui, W.; Karnati, S.; Zhang, X.; Burns, E.; Liou, F. Fabrication of AlCoCrFeNi High-Entropy Alloy Coating on an AISI 304 Substrate via a CoFe2Ni Intermediate Layer. Entropy 2019, 21, 2. [CrossRef]

18. Cui, W.; Zhang, X.; Li, L.; Chen, Y.; Pan, T.; Liou, F. Fabrication and Characterization of AlxCrCuFeNi2 High-Entropy Alloys Coatings by Laser Metal Deposition. Procedia Manuf. 2019, 39, 509-518. [CrossRef]

19. Wang, Y.P.; Li, B.S.; Ren, M.X.; Yang, C.; Fu, H.Z. Microstructure and compressive properties of AlCrFeCoNi high entropy alloy. Mater. Sci. Eng. A 2008, 491, 154-158. [CrossRef]

20. Tang, Z.; Senkov, O.N.; Parish, C.M.; Zhang, C.; Zhang, F.; Santodonato, L.J.; Wang, G.; Zhao, G.; Yang, F.; Liaw, P.K. Tensile ductility of an AlCoCrFeNi multi-phase high-entropy alloy through hot isostatic pressing (HIP) and homogenization. Mater. Sci. Eng. A 2015, 647, 229-240. [CrossRef]

21. Wang, R.; Zhang, K.; Davies, C.; Wu, X. Evolution of microstructure, mechanical and corrosion properties of AlCoCrFeNi high-entropy alloy prepared by direct laser fabrication. J. Alloy. Compd. 2017, 694, 971-981. [CrossRef]

22. Tsai, K.Y.; Tsai, M.H.; Yeh, J.W. Sluggish diffusion in Co-Cr-Fe-Mn-Ni high-entropy alloys. Acta Mater. 2013, 61, 4887-4897. [CrossRef]

23. Nong, Z.S.; Lei, Y.N.; Zhu, J.C. Wear and oxidation resistances of AlCrFeNiTi-based high entropy alloys. Intermetallics 2018, 101, 144-151. [CrossRef]

24. Mohanty, A.; Sampreeth, J.K.; Bembalge, O.; Hascoet, J.Y.; Marya, S.; Immanuel, R.J.; Panigrahi, S.K. High temperature oxidation study of direct laser deposited AlXCoCrFeNi $(X=0.3,0.7)$ high entropy alloys. Surf. Coat. Technol. 2019, 380, 125028. [CrossRef]

25. Butler, T.M.; Weaver, M.L. Oxidation behavior of arc melted AlCoCrFeNi multi-component high-entropy alloys. J. Alloy. Compd. 2016, 674, 229-244. [CrossRef]

26. Butler, T.M.; Alfano, J.P.; Martens, R.L.; Weaver, M.L. High-Temperature Oxidation Behavior of Al-Co-Cr-Ni-(Fe or Si) Multicomponent High-Entropy Alloys. JOM 2015, 67, 246-259. [CrossRef]

27. Dąbrowa, J.; Cieślak, G.; Stygar, M.; Mroczka, K.; Berent, K.; Kulik, T.; Danielewski, M. Influence of Cu content on high temperature oxidation behavior of AlCoCrCuxFeNi high entropy alloys $(\mathrm{x}=0 ; 0.5 ; 1)$. Intermetallics 2017, 84, 52-61. [CrossRef]

28. Feng, R.; Gao, M.C.; Zhang, C.; Guo, W.; Poplawsky, J.D.; Zhang, F.; Hawk, J.A.; Neuefeind, J.C.; Ren, Y.; Liaw, P.K. Phase stability and transformation in a light-weight high-entropy alloy. Acta Mater. 2018, 146, 280-293. [CrossRef]

29. Löbel, M.; Lindner, T.; Mehner, T.; Lampke, T. Influence of Titanium on Microstructure, Phase Formation and Wear Behaviour of AlCoCrFeNiTix High-Entropy Alloy. Entropy 2018, 20, 505. [CrossRef]

30. Jiang, S.; Lin, Z.; Xu, H.; Sun, Y. Studies on the microstructure and properties of AlxCoCrFeNiTi1-x high entropy alloys. J. Alloy. Compd. 2018, 741, 826-833. [CrossRef]

31. Tian, L.H.; Xiong, W.; Liu, C.; Lu, S.; Fu, M. Microstructure and Wear Behavior of Atmospheric Plasma-Sprayed AlCoCrFeNiTi High-Entropy Alloy Coating. J. Mater. Eng. Perform. 2016, 25, 5513-5521. [CrossRef]

32. Li, Q.H.; Yue, T.M.; Guo, Z.N.; Lin, X. Microstructure and corrosion properties of alcocrfeni high entropy alloy coatings deposited on AISI 1045 steel by the electrospark process. Metall. Mater. Trans. A Phys. Metall. Mater. Sci. 2013, 44, 1767-1778. [CrossRef]

33. Yu, Y.; Wang, J.; Li, J.; Kou, H.; Liu, W. Characterization of BCC phases in AlCoCrFeNiTix high entropy alloys. Mater. Lett. 2015, 138, 78-80. [CrossRef]

34. Bobbio, L.D.; Bocklund, B.; Otis, R.; Borgonia, J.P.; Dillon, R.P.; Shapiro, A.A.; McEnerney, B.; Liu, Z.K.; Beese, A.M. Characterization of a functionally graded material of Ti-6Al-4V to $304 \mathrm{~L}$ stainless steel with an intermediate V section. J. Alloy. Compd. 2018, 742, 1031-1036. [CrossRef]

35. Chen, S.; Zhang, M.; Huang, J.; Cui, C.; Zhang, H.; Zhao, X. Microstructures and mechanical property of laser butt welding of titanium alloy to stainless steel. Mater. Des. 2014, 53, 504-511. [CrossRef]

36. von Goldbeck, O.K. IRON_Binary Phase Diagrams; Springer: Berlin/Heidelberg, Germany, 1982.

37. Guan, S.; Solberg, K.; Wan, D.; Berto, F.; Welo, T.; Yue, T.M.; Chan, K.C. Formation of fully equiaxed grain microstructure in additively manufactured AlCoCrFeNiTi0.5 high entropy alloy. Mater. Des. 2019, 184, 108202. [CrossRef] 
38. Yu, Y.; Wang, J.; Li, J.; Yang, J.; Kou, H.; Liu, W. Tribological Behavior of AlCoCrFeNi(Ti0.5) High Entropy Alloys under Oil and MACs Lubrication. J. Mater. Sci. Technol. 2016, 32, 470-476. [CrossRef]

39. Munitz, A.; Salhov, S.; Hayun, S.; Frage, N. Heat treatment impacts the micro-structure and mechanical properties of AlCoCrFeNi high entropy alloy. J. Alloy. Compd. 2016, 683, 221-230. [CrossRef]

40. Chen, W.T.; Gleeson, B.; Heuer, A. Oxidation Behavior of $\gamma^{\prime}$-Ni3Al-Based Ni-20Al-5Cr Alloys with and without Reactive Elements Under Different Heating Conditions. Oxid. Met. 2019, 92, 137-150. [CrossRef]

41. Giggins, C.S.; Pettit, F.S. Oxidation of Ni-Cr-Al Alloys Between $1000^{\circ}$ and $1200^{\circ}$ C. J. Electrochem. Soc. 1971, 118, 1782. [CrossRef]

42. Zhang, P.; Li, Y.; Chen, Z.; Zhang, J.; Shen, B. Oxidation response of a vacuum arc melted NbZrTiCrAl refractory high entropy alloy at 800-1200 ${ }^{\circ} \mathrm{C}$. Vacuum 2019, 162, 20-27. [CrossRef]

43. Erdogan, A.; Doleker, K.M.; Zeytin, S. Effect of Al and Ti on High-Temperature Oxidation Behavior of CoCrFeNi-Based High-Entropy Alloys. JOM 2019, 71, 3499-3510. [CrossRef]

44. Laplanche, G.; Volkert, U.F.; Eggeler, G.; George, E.P. Oxidation Behavior of the CrMnFeCoNi High-Entropy Alloy. Oxid. Met. 2016, 85, 629-645. [CrossRef]

45. Kai, W.; Li, C.C.; Cheng, F.P.; Chu, K.P.; Huang, R.T.; Tsay, L.W.; Kai, J.J. Air-oxidation of FeCoNiCr-based quinary high-entropy alloys at 700-900 ${ }^{\circ}$ C. Corros. Sci. 2017, 121, 116-125. [CrossRef]

46. Wang, S.; Chen, Z.; Zhang, P.; Zhang, K.; Chen, C.L.; Shen, B.L. Influence of Al content on high temperature oxidation behavior of $\mathrm{Al}$ x CoCrFeNiTi 0.5 high entropy alloys. Vacuum 2019, 163, 263-268. [CrossRef]

47. Rashidi, S.; Choi, J.P.; Stevenson, J.W.; Pandey, A.; Gupta, R.K. Effect of Aluminizing on the High-Temperature Oxidation Behavior of an Alumina-Forming Austenitic Stainless Steel. JOM 2019, 71, 109-115. [CrossRef]

48. Wang, J.; Qiao, Y.; Dong, N.; Fang, X.; Quan, X.; Cui, Y.; Han, P. The Influence of Temperature on the Oxidation Mechanism in Air of HR3C and Aluminum-Containing 22Cr-25Ni Austenitic Stainless Steels. Oxid. Met. 2018, 89, 713-730. [CrossRef]

(C) 2020 by the authors. Licensee MDPI, Basel, Switzerland. This article is an open access article distributed under the terms and conditions of the Creative Commons Attribution (CC BY) license (http://creativecommons.org/licenses/by/4.0/). 